\title{
Rethinking Preschool Physical Design: Enhancing environmental stewardship among children
}

\author{
Mariam Felani Shaari ${ }^{1}$, Sabarinah Sh Ahmad ${ }^{1}$, Izaham Shah Ismail 2 \\ ${ }^{1}$ Faculty of Architecture, Planning \& Surveying, \\ 2Faculty of Education, \\ University Teknologi MARA, Malaysia \\ mariamfelani87@gmail.com
}

\begin{abstract}
Children are the future guardian of the Earth. Environmental Education (EE) at preschool level is crucial for instilling environmental stewardship. This paper discusses how preschool designs can be manipulated to facilitate and enhance the EE implementation. In summary, it is suggested that preschool settings should be designed to maximise children's interaction with nature. It not only helps to optimise children's development and literacy but also contributes to the prediction of their intentions to appreciate and to protect the environment. Findings are useful for Malaysian policy makers and designers in designing preschools that are sustainable and support EE.
\end{abstract}

Keywords: Malaysian preschool; green preschool design; children environmental behavior; environmental education

eISSN 2398-4295 @ 2018. The Authors. Published for AMER ABRA cE-Bs by e-International Publishing House, Ltd., UK. This is an open-access article under the CC BY-NC-ND license (http://creativecommons.org/licenses/bync-nd/4.0/). Peer-review under responsibility of AMER (Association of Malaysian Environment-Behaviour Researchers), ABRA (Association of Behavioural Researchers on Asians) and cE-Bs (Centre for EnvironmentBehaviour Studies), Faculty of Architecture, Planning \& Surveying, Universiti Teknologi MARA, Malaysia.

DOI: http://dx.doi.org/10.21834/ajbes.v3i13.150 


\subsection{Introduction}

Globalisation and environmental destruction go hand-in-hand - leading to detrimental effects such as climate change and global warming. Undoubtedly, the economic growth of developing countries such as Malaysia has been accompanied by environmental issues (Mat Said \& Paim, 2010), where pollution, use of fossil fuel and mass destruction of natural environments are prevalent (Marhani, Adnan \& Ismail, 2013). Unfortunately, the current unsustainable practices of consumption \& production threaten not only the environment but also the world's ecological systems and well-being. Realising this chain issues, The UNICEF Intergovernmental Panel on Climate Change (IPCC) concluded that only immediate and sustained actions would help halt climate change from causing permanent damage to our planet (UNICEF, 2012). This condition calls for immediate sustainable practices environmental destruction must stop, and the efforts to conserve and preserve the environment must start now.

To address this matter, Environmental Education (EE) has been recognised as one of the most important tools in promoting sustainable practices globally (Mat Said \& Paim, 2010; Sector, 2005; ASEAN EEAP, 2000). It helps to improve people's environmental knowledge as well as to nurture positive environmental attitude, values, and practices (UNESCO, 1977; Stapp, W.B., 1969). In Malaysia, EE is being implemented at various levels. At the school level, EE was first taught to the teachers through their training syllabus. EE was then introduced to the children at both primary and secondary schools in 1986 before being implemented at preschool level in 2003 (MOE, 2003).

However, the successful implementation of $E E$ in preschools requires access to a range of experiences indoor and outdoor of classrooms as they have a direct impact on the quality of learning opportunities available to children. Exploring different methods of manipulating preschool designs can help improve the implementation of EE. This paper aims to discuss how preschool designs can be tailored for successful Environmental Education (EE) implementation in Malaysian preschools. The objectives of the study are:

1. To examine the effects of natural environment on children.

2. To assess the current issues about the EE implementation in Malaysian preschools.

3. To discuss lessons learned on how preschool design elements can be manipulated to optimise children's development as well as to improve children's environmental literacy in the hope of nurturing their environmental stewardship.

\subsection{Literature Review}

\subsection{Effects of Natural Environment on Children}

\subsubsection{Benefits of interaction with nature}

The physical, socio-emotional and cognitive development takes place rapidly during the early childhood period (Abbas, Othman \& Rahman, 2012) and the natural environment plays an essential role in maximising the development (Olsen, 2015; McCurdy et al., 2010; Pretty et 
al., 2009). Moreover, children have a profound affinity towards nature. To them, nature is a sanctuary for explorative play and physical activity. It provides rough and dynamic playscape that will challenge and benefit themselves in all aspects of development, health and wellbeing (Azlina \& Zulkiflee, 2012; Fjørtoft, 2001). It encourages intellectual growth and cognitive learning the most - leading to better academic and non-academic achievements in the future (Chawla, 2015; Ahmad et al., 2015; Acar, 2014; Abbas, 2012; Cheng \& Monroe, 2012; Abbas \& Othman, 2011; Grinde \& Patil, 2009). It also helps improve their understanding of surroundings (Mohidin, Ismail \& Ramli, 2015). This condition proves that the consistent direct interaction with nature is crucial for children.

\subsubsection{Effects of nature deprivation}

Increasing deprivation and limited access to nature and its stimulative elements have led children to suffer from Nature Deficit Disorder (NDD). This condition is characterised by children's lack of interest and awareness of natural surroundings which affects the duration of time they spend playing in nature (Derr et al., 2013; Louv, 2009).

NDD among children is worrying, as it can potentially lead to unfavourable outcomes concerning mental, cognitive, physical and social development. NDD is related to the increasing number of health and well-being issues. This includes ADHD, high level of stress and anxiety, eczema, chronic asthma, type 2 diabetes, vitamin D deficiency, high blood pressure, childhood obesity and motor problems such as myopia (nearsightedness) (Montgomery, 2015; O'Brien \& Varley, 2012; Gray, 2011; McCurdy et. al., 2010). Apart from that, the majority of children who suffered from NDD also have an unhealthy attachment to electronic gadgets. The attachment contributes to various behavioural problems such as irregular sleep, violent tendencies and dampened creativity Due to the various health, wellbeing and behavioural related issues, children's academic performance will also be affected.

Moreover, recent research also suggests that a lack of interaction with nature among children makes it even harder to nurture environmental stewardships in them as it leads to their gross ignorance towards the natural environment. With minimal environmental awareness, knowledge, and attachment to nature, children as our future generations will show a lack of societal and political will to address environmental issues (Chawla, 2015; Gill, 2014; Shaumann, 2013; Nussbaum, 20112). For a country renowned for its diverse nature such as Malaysia, it is even more important that future generations are given the most opportunity to acquaint themselves with the environment they live.

\subsection{Environmental Education (EE) for Preschoolers}

\subsubsection{Nurturing young environmental stewards - preschoolers as active participants}

Environmental Education $(E E)$ is regarded as one of the most important tools in promoting sustainable practices globally (UNICEF, 2012; Mat Said \& Paim, 2010; Sector, 2005; ASEAN EEAP, 2000). Though children are among the most vulnerable to climate change, they must not be considered passive or helpless. They can act as potent agents to bring about change (Latif, Bidin \& Awang, 2013). Therefore, it is suggested that the earlier EE is implemented, the better as it gives opportunities for young children to be active participants to conserve 
and partake in efforts to preserve natural surroundings (Shaari et. al., 2016).

Children are the future guardian of the Earth. However, their concern for the environment is developed based on familiarity, love and affection. They need to have a long, direct and continuous contact with nature to to feel empathy, affinity, sense of belonging and responsible towards it (Chawla, 2015; Acar, 2014; Cheng \& Monroe, 2012; O’Brien \& Valey, 2012; Nussbaum, 2011; Abbas \& Ghazali, 2010). Therefore, they must be exposed and thought to appreciate nature and be nurtured to have the voluntary urge to become environmental stewards as early as possible (Azlina \& Zulkiflee, 2012; UNICEF, 2012) and the early EE implementation at preschool level enables that to happen.

The content of Environmental Education (EE) covers education 'about, for, in' the environment (NCC, 1990) that is explained as follows:

1. EE about the environment: Understanding the ecological principles (Relationships of nature \& human systems)

2. EE for the environment: Understanding the positive values, attitudes, actions for the environment

3. $E E$ in the environment: Inquiry, investigating, practicing in the environment

\subsection{Current Issues on the Environmental Education (EE) Implementation in Malaysian Preschools}

\subsubsection{Teachers' unpreparedness to teach EE}

Despite the EE content that requires access \& practices 'in' the natural environment, unfortunately, Malaysian preschool children are still encouraged to be indoors rather than outdoors. Malaysian preschools are still focusing too much on education 'about' the environment as well as 'for' the environment, but less on the education 'in' the environment. This issue is due to the unpreparedness to teach EE among Malaysian preschool teachers. Their minimal environmental awareness, knowledge, commitment and practices (Mat Said \& Paim, 2010) leads them to focus too much on the formal learning indoors, rather than outdoors. Children spend far more time being formally taught and evaluated on aspects of literacy and mathematic skills than they do, playing and exploring the natural world, exercising their bodies, and using their imaginations to express themselves (Azlina \& Zulkiflee, 2012). This issue is proved by the high level of environmental knowledge and the moderate level of the $3 R$ practices among the Malaysian preschoolers (Mahat, Mohamad \& Ngah, 2016).It is believed that the successful EE implementation is significantly dependent on the teachers' knowledge and commitment (Pudin et. al., 2005; Cutter \& Smith,2001).

\subsubsection{Parents' fear}

Constrained behaviour exhibited by parents may result in less outdoor play among children. Parents' perceived risk includes 'stranger danger' (abduction by strangers), traffic accidents due to busy roads, and hazardous trees. Besides, harsh weather (exposure to the sun, rain and snow), dangerous play equipment as well as messy and dirty play are also included (Carver et. al., 2010; Bringolf-Isler et al, 2010; Valentine \& McKendrck, 1997). For the teachers, it is better to respond to the parents' fear and provide a safe and precautionary 
indoor play for children rather than to give into speculations about possible legal action (Davis, 1998).

\subsubsection{Children's attachment to gadget}

There is an increased tendency to play and be entertained in front of TVs, game consoles and smartphones rather than go outside and play. This worrying condition is becoming more apparent among children nowadays, especially in urban areas in both developed and developing countries (Chawla, 2015). Thus, makes it even harder to teach them about and connect them with the natural environment.

\subsubsection{Preschool buildings are not purposely designed to accommodate EE implementation}

Although the Malaysian preschool system has long been established in 1920's, it was only recently that the EE is incorporated into the National Preschool Curriculum (Mat Said \& Paim, 2010). Thus, most of the preschool buildings were not purposely built for the EE implementation.

\subsection{Preschool Physical Design: Enabling Environmental Education (EE)}

\subsubsection{Theoretical foundation}

\begin{tabular}{|c|} 
Encourage \\
interaction \\
with nature
\end{tabular} $\overrightarrow{\begin{array}{c}\text { Ensure } \\
\text { effective } \\
\text { interaction } \\
\text { with } \\
\text { natural } \\
\text { elements }\end{array}} \Rightarrow \overrightarrow{\begin{array}{c}\text { Increased } \\
\text { affection \& } \\
\text { appreciation } \\
\text { of natural } \\
\text { elements }\end{array}} \Rightarrow \overrightarrow{\begin{array}{c}\text { Positive } \\
\text { attitudes } \\
\text { towards } \\
\text { environment }\end{array}} \Rightarrow \overrightarrow{\begin{array}{c}\text { Ultimately, } \\
\text { sense to } \\
\text { preserve the } \\
\text { natural } \\
\text { environment }\end{array}}$

Figure 1: A theoretical approach to environmental education-friendly preschools.

(Chawla, 2015; Kelz, Evans \& Röderer, 2015; Olsen, 2015; Azlina \& Zulkiflee, 2012; Thompson, Aspinall \& Montarzino, 2007)

Figure 1 summarises the theoretical approach (based on the Theory of Planned Behaviour) commonly adopted in developed countries to design Environmental Education (EE)-friendly preschools. The Theory of Planned Behavior suggests that constant and active connection and identification with the surrounding nature would contribute significantly to the prediction of a person's intentions to appreciate and to preserve it (Hinds \& Sparks, 2007). In other words, the theory indicates that to ensure that desired behaviours can successfully be nurtured among preschool children, promoting their effective interaction with natural elements acts as the key factor - this is where the preschool physical design come into play. In fact, the manipulation of preschool physical design to promote responsibility towards the natural environment among children have long been supported by various studies (Kelz, Evans \& Röderer, 2015; Hinds \& Sparks, 2007; O’Brien \& Murphy, 2007). 
2.4.2 Linking Environmental Education (EE) with National Preschool Curriculum (NPC) EE in Malaysian preschools is not taught as a single subject but incorporated in NPC under the Creativity and Aesthetic Component (Mat Said \& Laily, 2010). Therefore, in assisting the Theory of Planned Behaviour implementation, the preschool settings must be designed to facilitate the current preschool educational programs - allowing seamless and effective integration of EE into the NPC and ensuring all educational objectives are achieved.

\subsubsection{Maximising the Environmental Education (EE): Rethinking the outdoor play}

The current focus for many preschool outdoor play is on the maximising the children's development as well as a source of creativity play, ideas, and inspiration. However, preschool outdoor play should extend beyond that practice. There are also significant environmental elements to be learned while playing outdoor. Children can learn about how the ecosystem works. They get to learn about and taking responsibility to protect the plants and animals. Children can also learn sustainable practices to maintain that ecosystem. They can be active participants in waste recycling and reduction as well as energy efficiency practices. They can learn the importance of conserving the resources rather than consuming. In overall, the outdoor play focus should not be limited in maximising children's development but also aims in maximising their environmental understanding and nurturing positive behaviour for environmental change.

\subsubsection{Encouraging children's interaction with nature: Redesigning the outdoor play environment}

Despite many benefits natural environment has on children (Ahmad et al., 2015; Soltani, Abbas \& Awang, 2012), the opportunity given to them to engage in nature is significantly reduced. Nowadays, parents work longer hours. Thus, children visits to the backyard or local parks become lesser. Some parents substitute their presence with any other organised educational and recreational activities and even worst, with electronic gadgets for their children. At the preschool level, many owners, planners, and regulators operating their preschools with minimal outdoor play opportunities. Some of them are focusing on profit making by purposely expanding internal space leaving grossly small outdoor play space for children (Davis, 1998).

Even though indoor built environments are safer, more structured and better planned, they lack features to provide critical stimulation children need to learn and develop. Environmental stewardship is also harder to be nurtured without consistent direct connection to nature. Thus, to support both types of education, the preschool setting must be designed to incorporate both outdoor natural and indoor built environments and ensure that they work in synergy in maximising children development as well as environmental stewardship (Abbas, 2012; Abbas, Othman \& Rahman, 2012; Grinde \& Patil, 2009). Also, considering various issues on EE implementation in preschools, redesigning preschool designs should be able to provide solutions to some of the problems. 


\subsection{Methodology}

The methodology used in this paper is a comprehensive review of secondary data. Qualitative analyses of findings were employed. Both quantitative and qualitative literature from various disciplines related to the title were gathered and critically analysed. Three electronic databases were searched: Science Direct, Scopus, and Web of Knowledge indexing Malaysian and international journals on a variety of environmental education related topics from 1980 to the present. In doing so, the following keywords were searched; Malaysian preschool, green preschool design, children environmental-behavior, environmental education, using titles and descriptors.

The paper started with the general understanding of the impact of natural environment on children development, followed by exploring environmental education for children, to understand the need to nurture environmental stewards as early as possible. Preschool physical design from various locations globally was then explored, to understand how they can be tailored to support the environmental education implementation.

Limitation of this paper includes, mainly the challenges encountered during data collection - the heavy emphasis given to the physical aspect of preschool design. Literature is examined from viewpoints which are only confined to the context of the studies and topics discussed, which may render recommendations non-holistic.

The common design strategies of environmental education-friendly preschools used in other countries were summarised, and further reviewing of all concepts were suggested. A holistic approach and expert reviewing are highly recommended to ensure that foreign design concepts are applicable in the Malaysian context. Gaps for further research identified from the analysis were also suggested.

\section{Results, Discussion, and Recommendation}

Figure 2 below summarises the recommended design aspects that should be adopted in designing Malaysian preschools for the successful Environmental Education (EE) implementation.

The recommended design strategies encourage children's familiarity with nature and ensure that they are consistently in proximity with diverse natural elements throughout their time in preschools. The strategies are also coherent with the theoretical approach highlighted in Figure 1 - the first step towards successful Environmental Education (EE) is to encourage interaction with nature.

In trickier situations, where space is limited, such as in crowded urban areas, designers can instead devise preschool physical environments that work in ensuring that children are regularly exposed to natural elements even though they are indoors - indirectly making children involved with nature. Apart from maximising children interaction with nature, it also helps to manage the unwanted risks associated with outdoor activity among children. Which include, air and noise pollution (especially in urban areas), animal bites (especially in tropical countries), communicable diseases and accidents during outdoor play (Ghanbari-Azarneir et al., 2015). 


\section{WELCOMING ATMIOSPHERE}

+ Clean

- Propar vensiafion 5 Adequate netural fightirg

+ Open learring \& play spaces (minimat obetruction)

+ Friendy \& inviting - Use of warm and asprcpriete colors to strmulate comfort

- Equpped with approprate slorape for childen \& stalf use

\section{ADEQUATE OUTDOOR PLAY GPACE}

- Märimai requirement $7 \mathrm{mr}^{2}<$ Alleast $>10 \mathrm{~m}^{2}$

\section{ADQUATE OUTDOOR SHADED AREAS}

+ Protection from UV rediation of surlight

\section{ADEQUATELY FENCED}

+ Mirimising acoses of unatitionised pecple and animals

\section{AGE APPROPRIATE}

+ All furribure 8 focilitien must be chid-triencly to enable them so interact effectively

- Devoid of sharp edoes. Use eporoptiaha height \& gale matarials

\section{COOD VISEIUTY \& ACCESS}

+ Oufdoor play areas are onvenienty accessble \& within teachers' superviaion

\section{OUTOOOR PLAY AREAS AS EXTENSION OF INDOOR CLASSAOOM}

+ fambier environmants that hap chicden foel safe and weicomed

- Children show the highest degree of interest in playgrounds thet heve a combhation of both elaments

inatural 8 man-made? - therefore there must be a betenced conbinetion of both

\section{GFEENING THE PRESCHOOL. GROUND}

\section{- ANIMALS PETTING AREA}

+Animais caring activitias

- GARDEN AFEA

- Plariting activities

- Reflect beel raturai habitat

- Altroct nativo wildifo (if posesibia)

-PLANTS

- Plerits are carefully selected to minimine tisks to chilidren

+ OUTDOOR PLAY AREAS

- Water play area

- Sand play araa

- Napural conbours for physical play

- NATURAL \& RECYCLED MATERIALS AS PLAY EQUIPMENT

- Natural (trees, rocka, sand, serth. water) 8 manufactured loces materiels are recycled as manicuative

play equpments

- RECYCLING BIN

- Placing recycling bins in classrooms $\&$ oudoor play yerd

- Encoursog fecycling habe

- WASTE BIN

- Avoid Ittering

- NATURE OBSERVATON \& EXPERIMENTATION

- Create ckpcrtunities to explone 8 experienoe nature

+ ENVIRONMENTAL MESSAGES THROUGH PANTINGS AND MURALS

- Visually incorporating massagos on how to pratect the emvronment

- Plecirg pictures of various common species of flore \& feuna

\section{GREENANG THE INDOOR CLASSROOM}

+ Good natiral lighiting S erierey efficient

- Good indoor ar quality 8 venstation

- Incorporate plants 8 nacure into most common indoor aresa - childen are conetanty exposed to natura edements ever though they are indoors

Figure 2: How outdoor play areas of preschools should be designed?

(Source: Ghanbari-Azarneir et al., 2015; Kelz, Evans \& Röderer, 2015; Spencer \& Wright, 2014; Acar, 2014; Kelz, Evans \& Röderer, 2013; Latif, Bidin \& Awang, 2013; Azlina \& Zulkiflee, 2012; Ramli et al., 2012; UNICEF, 2012; Hinds \& Sparks, 2007) 


\subsection{Conclusion}

In summary, even though most design concepts implemented in other countries have the potential to be implemented in Malaysia, they must go through expert reviewing by a multidisciplinary panel which includes practitioners from various backgrounds. Not all of the approaches used are applicable in Malaysia due to certain social, administrative and geographical issues - design concepts have to be adapted and induced by Malaysian educators to ensure that many aspects of children education are properly considered.

Designing preschool environments for Environmental Education (EE), however, primarily revolve around allowing safe but continuous and uninterrupted contact between children and natural elements. This concept should be the foundation of all preschool design in Malaysia to ensure that future generations are better equipped to combat and respond to global climate change. It is hoped that findings from this paper can then be reviewed and analysed to ensure effective implementation in Malaysia. Environmental stewardship beginning with children is the key to a greener Malaysia.

Some successful design strategies can be tailored to suit Malaysian settings. Reviews from experts may include those from fields of children education, paediatric medicine and psychology, architecture and urban planning and government personnel. Issues, for example, shading, and preschool orientation must be seriously considered because of Malaysia's hot and humid climate. European preschools can afford to have open playgrounds with minimal shading, while Malaysian preschools cannot. Due to high UV levels and undesirable temperatures, maximising indoor natural lighting can also be tricky - unlike countries in seasonal climates, Malaysian preschools cannot just simply allow maximal unobstructed exposure to natural light, especially during midday. But fortunately, this should not hinder Malaysians from exploring other possible avenues to implement the key design strategies implemented in other countries. With more study and better grasps of the fundamental principles of Environmental Education (EE), efforts will be easier to transform Malaysian preschools into institutions of environmental learning.

\section{Acknowledgement}

The authors would like to thank the Ministry of Higher Education, Malaysia, for the funding given under the Fundamental Research Grant Scheme (FRGS). The authors would also like to thank IRMI, Universiti Teknologi MARA for administering the grant.

\section{References}

Abbas, M. Y., \& Othman, M. (2011). Social Behaviours between Urban and Non-Urban Pre-School Children. Procedia-Social and Behavioral Sciences,30, 2001-2009.

Abbas, M. Y., Othman, M., \& Rahman, P. Z. M. A. (2012). Pre-school Classroom Environment: Significant upon Childrens' Play Behaviour?.Procedia-Social and Behavioral Sciences, 49, 47-65

Acar, H. (2014). Learning Environments for Children in Outdoor Spaces.Procedia-Social and Behavioral 
Sciences, 141, 846-853.

Ahmad, S. S., Shaari, M. F., Hashim, R., \& Kariminia, S. (2015). Conducive Attributes of Physical Learning Environment at Preschool Level for Slow Learners. Procedia-Social and Behavioral Sciences, 201, 110-120.

ASEAN Environmental Education Action Plan (EEAP). (2000). Retrieved on May 30, 2017 from http:// www.asean.or.id/10753.htm.

Azlina, W., \& Zulkiflee, A. S. (2012). A pilot study: The impact of outdoor play spaces on kindergarten children. Procedia-Social and Behavioral Sciences,38, 275-283.

Bringolf-Isler, B., Grize, L., Mäder, U., Ruch, N., Sennhauser, F. H., \& Braun-Fahrländer, C. (2010). Built environment, parents' perception, and children's vigorous outdoor play. Preventive medicine, 50(5), 251-256.

Carver, A., Timperio, A., Hesketh, K., \& Crawford, D. (2010). Are children and adolescents less active if parents restrict their physical activity and active transport due to perceived risk?. Social science \& medicine, 70(11), 17991805.

Chawla, L. (2015). Benefits of Nature Contact for Children. Journal of Planning Literature, 30(4), 433-453, 0885412215595441.

Cheng, J. C. H., \& Monroe, M. C. (2012). Connection to Nature Children's Affective Attitude toward Nature. Environment and Behavior, 44(1), 31-49.

Cutter, A., \& Smith, R. (2001). Gauging primary school teachers' environmental literacy: An issue of 'priority'. Asia Pacific Education Review, 2(2), 45-60.

Davis, J. (1998). Young children, environmental education, and the future. Early Childhood Education Journal, 26(2), 117-123.

Derr, V., Chawla, L., Mintzer, M., Cushing, D. F., \& Van Vliet, W. (2013). A city for all citizens: Integrating children and youth from marginalized populations into city planning. Buildings, 3(3), 482-505.

Fjørtoft, I. (2001). The natural environment as a playground for children: The impact of outdoor play activities in preprimary school children. Early childhood education journal, 29(2), 111-117.

Ghanbari-Azarneir, S., Anbari, S., Hosseini, S. B., \& Yazdanfar, S. A. (2015). Identification of Child-friendly Environments in Poor Neighborhoods.Procedia-Social and Behavioral Sciences, 201, $19-29$.

Gill, T. (2014). The benefits of children's engagement with nature: A systematic literature review. Children Youth and Environments, 24(2), 10-34.

Gray, P. (2011). The decline of play and the rise of psychopathology in children and adolescents. American Journal of Play, 3(4), 443-463.

Grinde, B., \& Patil, G. G. (2009). Biophilia: does visual contact with nature impact on health and wellbeing?. International journal of environmental research and public health, 6(9), 2332-2343.

Hinds, J., \& Sparks, P. (2008). Engaging with the natural environment: The role of affective connection and identity. Journal of Environmental Psychology, 28(2), 109-120.

Horayangkura, V. (2012). Incorporating environment-behavior knowledge into the design process: An Elusive Challenge for Architects in the 21st Century.Procedia-Social and Behavioral Sciences, 50, 30-41. 
Intergovernmental Panel on Climate Change (2007) 'Climate Change: The physical science basis', Fourth Assessment Report, IPCC, Geneva, accessed on the 10 February 2016 from https://www.ipcc.ch/publications_and_data/publications_ipcc_fourth_assessment_report_wg1_report_the_physical _science_basis.htm

Kelz, C., Evans, G. W., \& Röderer, K. (2013). The restorative effects of redesigning the schoolyard: A multimethodological, quasi-experimental study in rural Austrian middle schools. Environment and Behavior, 0013916513510528.

Latif, S. A., Bidin, Y. H., \& Awang, Z. (2013). Towards the Realization of Green Cities: The moderating role of the residents' education level. Procedia-Social and Behavioral Sciences, 85, 646-652.

Louv, R. (2009). Do our kids have nature-deficit disorder. Educational Leadership, 67(4), 24-30.

Mahat, H., Mohamad, S. Y., \& Ngah, C. (2016, January). 3R Practices Among Moe Preschool Pupils through the Environmental Education Curriculum. In SHS Web of Conferences (Vol. 23). EDP Sciences.

Mat Said, A., \& Paim, L. (2010).Preparedness of Malaysian preschool educators for environmental education. Pertanika Journal of Social Sciences \& Humanities, 18(2),271-283.

McCurdy, L. E., Winterbottom, K. E., Mehta, S. S., \& Roberts, J. R. (2010). Using nature and outdoor activity to improve children's health. Current problems in pediatric and adolescent health care, 40(5), 102-117.

Ministry of Education (MOE). (2003). National Pre-school Curriculum. Kuala Lumpur: Fajar Bakti Press

Mohidin, H. H. B., Ismail, A. S., \& Ramli, H. B. (2015). Effectiveness of Kindergarten Design in Malaysia. ProcediaSocial and Behavioral Sciences,202, 47-57.

Nussbaum, M. C. (2011). Creating Capabilities. Cambridge, MA: Harvard University Press.

Montgomery, J. (2015). Nature as Healer and Teacher-The Importance of Reconnecting Children to the Earth for Physical and Emotional Wellbeing (Doctoral dissertation, City University of Seattle).

NCC. (1990).CurriculumGuidance7:Environmental Education, NCC, York.

O'Brien, L., \& Varley, P. (2012). Use of ethnographic approaches to the study of health experiences in relation to natural landscapes. Perspectives in public health, 132(6), 305-312.

Olsen, H. M. (2015). Planning Playgrounds: A Framework to create Safe and Inclusive Playgrounds, Journal of Facility Planning, Design and Management, 3 (1), 57-71.

Pretty, J., Angus, C., Bain, M., Barton, J., Gladwell, V., Hine, R., ... \& Sellens, M. (2009). Nature, childhood, health and life pathways. Occasional Paper, 2.

Pudin, S., Tagi, K., \& Periasamy, A. (2005, January). Environmental education in Malaysia and Japan: A comparative assessment. In Education for a sustainable future international conference, Ahmedabad, India. http://www. ceeindia. org/esf/download/paper20. pdf.

Ramli, N. H., Masri, M. H., Zafrullah, M., Taib, H. M., \& Hamid, N. A. (2012). A comparative study of green school guidelines. Procedia-Social and Behavioral Sciences, 50, 462-471.

Schauman, S. (2013). The Genius of Childhood: The Life and Ideas of Edith Cobb. Children Youth and Environments, 23(2), 194-207. 
Shaari, M. F., Ahmad, S. S., \& Ismail, I. S. (2016). Nurturing Environmental Stewards through Preschool Physical Design. Environment-Behaviour Proceedings Journal, 1(3), 3-12.

Soltani, S. H. K., Abbas, M. Y., \& Awang, M. B. (2012). Disabled children in public playgrounds: A pilot study. Procedia-Social and Behavioral Sciences,36, 670-676.

Spencer, K. H., \& Wright, P. M. (2014). Quality Outdoor Play Spaces for Young Children. YC Young Children, 69(5), 28-34.

Stapp, W. B. (1969). The concept of environmental education. Environmental Education, 1(1), 30-31.

UNESCO, U. (1977). The Tbilisi Declaration. In Intergovernmental Conference on Environmental Education.

Thompson, C. W., Aspinall, P., \& Montarzino, A. (2007). The childhood factor: Adult visits to green places and the significance of childhood experience.Environment and Behavior.

UNICEF (2012). Climate Change and Environmental Education, accessed on the 12 February 2016 on the http://www.unicef.org/publications/files/CFS_Climate_E_web.pdf

Sector, U. E. (2005). United Nations Decade of Education for Sustainable Development (2005-2014): International Implementation Scheme. UN Educ Sci Cult Organ UNESCO Paris Fr.

Valentine, G., \& McKendrck, J. (1997). Children's outdoor play: exploring parental concerns about children's safety and the changing nature of childhood. Geoforum, 28(2), 219-235.

Yerkes, R. (1982). A Playground that Extends the Classroom. ERIC. Document 239802. Vol.6, No.4 (Winter), Miami University. 